\title{
Calyptospora sp. in Brachyplatystoma vaillantii trapped at the Vigia, State of Pará, Brazil
}

\author{
Calyptospora sp. em Brachyplatystoma vaillantii capturadas no município de Vigia, Estado do Pará, Brasil \\ Moacir Cerqueira da Silva ${ }^{1 *}$; Sérgio Carmona da São Clemente ${ }^{2}$; \\ José Antônio Picanço Júnior ${ }^{3}$; Michele Velasco Oliveira da Silva ${ }^{4}$; Edilson Rodrigues Matos ${ }^{4}$ \\ ${ }^{1}$ Instituto da Saúde e Produção Animal, Universidade Federal Rural da Amazônia - UFRA, Belém, PA, Brasil \\ ${ }^{2}$ Faculdade de Veterinária, Universidade Federal Fluminense - UFF, Niterói, RJ, Brasil \\ ${ }^{3}$ Laboratório de Microscopia Eletrônica, Instituto Evandro Chagas - IEC, Belém, PA, Brasil \\ ${ }^{4}$ Laboratório de Pesquisas Carlos Azevedo, Instituto da Saúde e Produção Animal, Universidade Federal Rural da Amazônia - UFRA, \\ Belém, PA, Brasil
}

Received July 18, 2011

Accepted December 19, 2011

\begin{abstract}
The article describes the first occurrence of hepatic coccidiosis in catfish of the species Brachyplatystoma vaillantii, captured in the coastal region of the Vigia city, state of Pará, Brazil, caused by species of the genus Calyptospora, family Calyptosporidae. Thirty specimens of piramutabas were examined where $60 \%$ were infected with liver location, featuring numerous mature and immature oocysts, grouped or isolated, with four sporocysts in pyriform shape. They were described on their morphology and dimensions of the oocysts and sporocysts, obtained from light microscopy and differential interference contrast.
\end{abstract}

Keywords: Coccidiosis, Brachyplatystoma vaillantii, Calyptospora, Piramutaba, liver.

\section{Resumo}

O artigo descreve a primeira ocorrência de coccidiose hepática em bagres da espécie Brachyplatystoma vaillantii, capturados na regiáo costeira do Município de Vigia, Estado do Pará, Brasil, causada por espécies do gênero Calyptospora, família Calyptosporidae. Foram examinados trinta exemplares de piramutabas, dos quais $60 \%$ encontravam-se parasitados com localização hepática, apresentando vários oocistos maduros e imaturos, agrupados ou isolados, com quatro esporocistos de formato piriforme. Sáo descritas as características morfológicas e dimensóes dos oocistos e esporocistos, obtidas a partir de microscopia de luz em campo claro e em contraste interferencial de fases.

Palavras-chave: Coccidiose, Brachyplatystoma vaillantii, Calyptospora, piramutaba, fígado.

Coccidia comprise a large group of obligate intracellular parasites frequently found in all classes of vertebrate hosts as well as in some invertebrates. Some pathogenic and parasitic forms affect mollusks and fish (MATOS et al., 2004). Indeed, coccidia are common in marine and freshwater fish including the genus Calyptospora (DAVIES; BALL, 1993; MOLNÁR, 2006). The family Calyptosporidae was first described in fishes by Overstreet et al. (1984) and comprises only five species: Calyptospora funduli (OVERSTREET et al., 1984); C. empristica (FOURNIE et al., 1985); C. serrasalmi (CHEUNG et al., 1986);

\footnotetext{
${ }^{*}$ Corresponding author: Moacir Cerqueira da Silva

Instituto da Saúde e Produção Animal, Universidade Federal Rural da Amazônia - UFRA, Av. Pte. Tancredo Neves, 2501, Terra Firme, CEP 66077-530, Belém, PA, Brasil

e-mail: moacir_silva@oi.com.br
}

C. tucunarensis (BÉKÉSI; MOLNÁR, 1991), and C. spinosa (AZEVEDO et al., 1993).

Three species of the genus have been described parasitizing the liver of Brazilian fish: C. serrasalmi in Serrasalmus niger (CHEUNG et al., 1986), C. tucunarensis in Cichla ocellaris (BÉKÉSI; MOLNÁR, 1991), and C. spinosa in Crenicicha lepidota (AZEVEDO et al., 1993). Moreover, Bonar et al. (2006) reported the occurrence of Calyptospora sp. and Dawestrema cycloancistrium (Ancyrocephalinae) in seven juvenile specimens of fish species Arapaima gigas (aka pirarucu) which were exported from Manaus to the USA and became ill died four to six weeks after arrival showed lesions mainly in the liver, gills, brain, and gastrointestinal tract. Further, among the most common parasites found in the Amazon fish, Azevedo et al. (1993) found C. spinosa in fish of the species Hoplosternum littorale (aka tamoatá) and in Crenicichla lepidota (aka jacundá), all naturally occurring in the Amazon River basin. 
There is a lack of studies on ictioparasitoses in fish of high economic value such as the one contemplated by this study (Piramutaba Brachyplatystoma vaillantii,). Such knowledge is important to correlate disease outbreaks with biotic and abiotic factors and for implementation of necessary mitigation measures to avoid or minimize the impact on fish stocks. Thus, the objective of this study was to describe the morphology of Calyptospora oocysts found in the liver of $B$. vaillantii, by conventional light microscopy and differential interference contrast and thereby to make an initial assessment of the coccidiosis affecting this fish from the Amazon River basin.

\section{Material and Methods}

Thirty specimens of B. vaillantii weighing $380-450 \mathrm{~g}$ and measuring between 28.5 and $45.5 \mathrm{~cm}$ were captured in the estuary at the Municipality of Nazareth Vigia in the State of Pará, Brazil $\left(00^{\circ} 51^{\prime} \mathrm{S}\right.$ and $\left.48^{\circ} 08^{\prime} \mathrm{W}\right)$ by fishermen and donated to this study. The specimens were necropsied following the methods described by Azevedo et al. (1993). To highlight the oocysts, sporocysts, and sporopodium contours we employed differential interference contrast (Nomarski) optics.

\section{Results and Discussion}

In fresh preparations of the 18 B. vaillantii specimens found positive for liver coccidiosis and, a large amount of grouped and isolated spherical oocysts were observed (Figure 1a). In many cases, the host hepatic parenchyma was replaced by numerous groups of oocysts, distributed irregularly. Azevedo et al. (1993) found infections in which the liver of the host $C$. lepidota also held numerous groups of oocysts of Calyptospora sp. arranged irregularly in the liver parenchyma.

The main organ affected by Calyptospora sp. in the examined fish was the liver, corroborating the findings reported for Arapaima gigas (ALBUQUERQUE; BRASIL-SATO, 2010), C. lepidota (AZEVEDO et al., 1993; 1995), C. ocellaris (BÉKÉSI; MOLNÁR, 1991), fishes of the genus Serrasalmus (CASAL et al., 2007), S. niger (CHEUNG et al., 1986), and Fundulus notti(FOURNIE et al., 1985). The prevalence of infected livers disease was $60 \%$, a finding similar to the rates reported by Azevedo et al. (1993) and Békési and Molnár (1991) in studying the infectious diseases caused by Calyptospora in fish species.

Morphological analysis revealed several groups of spherical oocysts, each containing four pirifom sporocysts (Figure 1c), within which sporozoites and sporodiums with lateral projections were found (Figure 1b). Similar findings were reported previously by Azevedo et al. (1993) in C. lepidota, parasitized by C. spinosa. These findings are expected for the genus Calyptospora, which was originally shown to infect fish species by Overstreet et al. (1984).

Measurements showed that the mean diameter of oocyts was $20.8 \mu \mathrm{m}$, and the mean length and width of sporocysts were 8.9 and $4.15 \mu \mathrm{m}$, respectively. The biometric data obtained from sporulated oocysts were similar to those described by Fournie et al. (1985) regarding C. empristica, Duszynski et al. (1979) for C. funduli, Cheung et al. (1986) for C. serralsalmi, Békési and Molnár (1991)

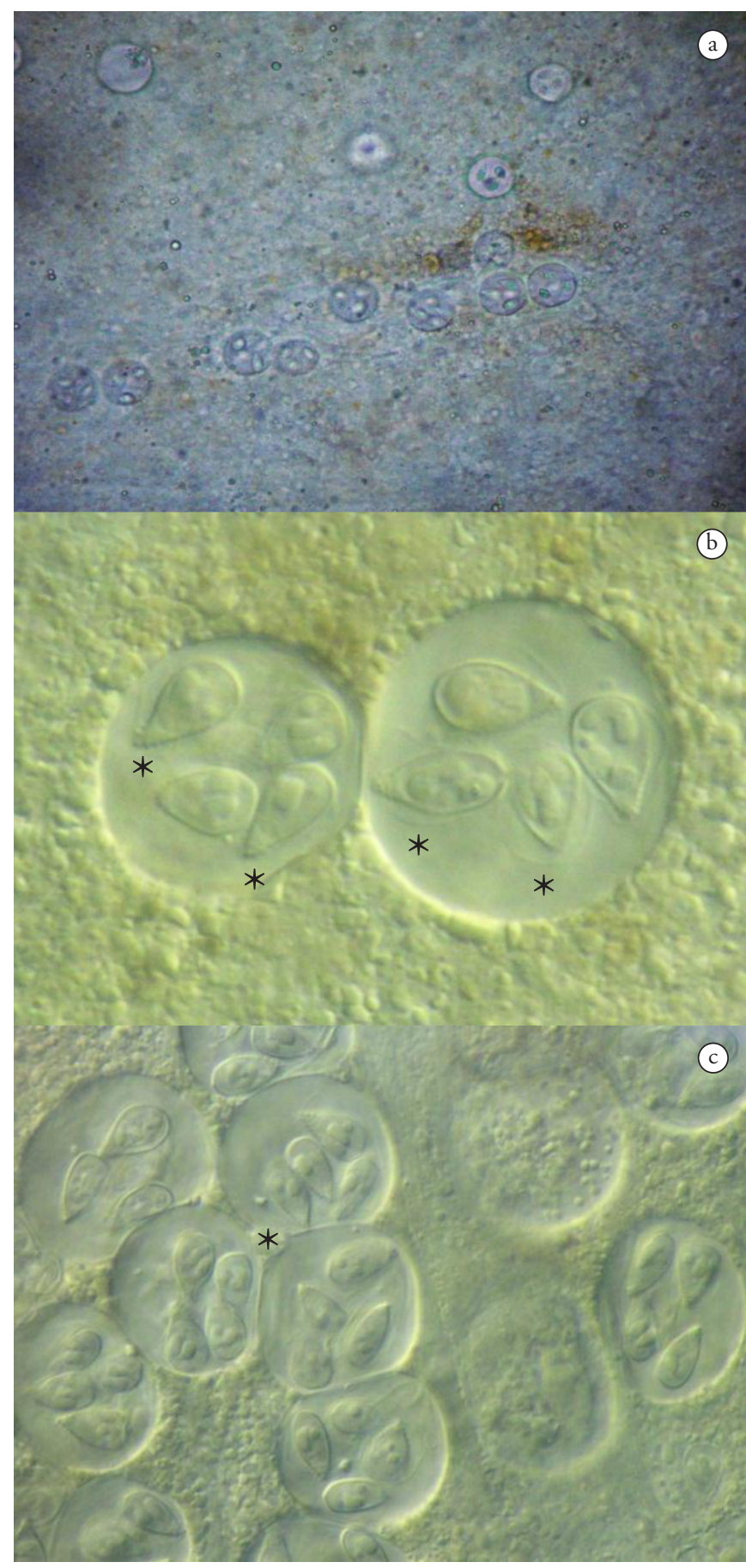

Figure 1. Calyptospora sporulated oocysts a) isolated and grouped, containing four sporocysts and distributed among liver cells of B. vaillantii. Fresh preparation, 400X.; b) Two sporocysts showing sporopodium with lateral projections (small arrow) and the veil (arrowheads) Nomarski, 1000X.; c) Grouped of sporulated oocysts among liver cells of B. vaillantii $\left(^{*}\right)$. Nomarski, 1000X.

for C. tucunarensis, Azevedo et al. (1993) for C. spinosa, Bonar et al. (2006) for Calyptospora sp. and Albuquerque and Brasil-Sato (2010) for Calyptospora sp.

Table 1 shows the comparative biometric data regarding sporulated oocyst size and shape, and sporocyst length and 
Table 1. Comparative measurements of sporulated oocysts and sporocysts of the genus Calyptospora.

\begin{tabular}{lcccccl}
\hline \multicolumn{1}{c}{ Species } & Origen & $\begin{array}{c}\text { Oocyst } \\
\text { diameter }\end{array}$ & Form & Sength & Width & Reference \\
\cline { 3 - 5 } & & $(\boldsymbol{\mu} \mathbf{m})$ & & & & \\
\hline C. empristica & USA & $19.6-24.5$ & Elliptical & $7.0-9.5$ & $4.5-7.5$ & Fournie et al. (1985) \\
C. funduli & USA & $20.0-31.0$ & Ovoid & $9.0-11.0$ & $5.0-7.0$ & Duszynski et al. (1979) \\
C. serrasalmi & Brazil & $22.0-25.0$ & Piriform & $10.0-11.5$ & $5.0-6.0$ & Cheung et al. (1986) \\
C. tucunarensis & Brasil & $23.0-26.0$ & Racket, Elliptical body & $7.2-9.1$ & $3.5-5.0$ & Békési and Molnár (1991) \\
C. spinosa & Brazil & $21.1-23.4$ & Elliptical & $8.9-9.5$ & $3.6-4.1$ & Azevedo et al. (1993) \\
Calyptospora sp. & Brazil & $16.0-22.0$ & Piriform & $8.0-10.0$ & $4.5-5.0$ & Bonar et al. (2006) \\
Calyptospora sp. & Brazil & 24.5 & - & 11.5 & 4.5 & Albuquerque and Brasil-Sato (2010) \\
Calyptospora sp. & Brazil & 20.8 & Piriform & 8.9 & 4.1 & Current study \\
\hline
\end{tabular}

width, of the Calyptospora species described in the literature. A new morphological and structural description of C. serrasalmi revealed mean oocyst diameter of $25.4 \mu \mathrm{m}$ (CASAL et al., 2007). Although the mean oocyst size found in the present study is smaller than that reported by Casal et al. (2007), it is similar to that described for C. spinosa by Azevedo et al. (1993). Analyses of shape and size of spocysts revealed they were similar to those reported for C. serrasalmi by Cheung et al. (1986) and Calyptospora sp. by Bonar et al. (2006), both studying Brazilian fishs.

The morphological and biometrical characteristics of the oocysts and sporocysts observed by light and Normarski microscopy, suggest that they belong to species of the genus Calyptospora; since coccidia oocysts of this taxonomic category are spherical and of similar size; and each contain four sporocysts. This finding corroborates the evidence reported by Azevedo et al. (1993), who noted the morphological similarity between sporocysts of C. fundulea, C. empristica, C. serrasalmi, and C. tucunarensis, also observed in this study.

\section{Conclusion}

This study extend the occurrence of Calyptospora sp. for a new Neotropical host, the piramutaba $B$. vaillantii.

\section{Acknowledgements}

This study was supported by the Coordenação de Aperfeiçoamento de Pessoal de Nível Superior pela bolsa de estudos (CAPES). We thank the Instituto Acquamazon for providing access to the fish, the Laboratório de Pesquisas Aquáticas Carlos Azevedo of the Universidade Federal Rural da Amazônia for helping with the histopathological studies, and the Laboratório de Microscopia Eletrônica do Instituto Evandro Chagas for help with Normaski optics and the Andrea Kaufmann-Zeh PhD. for revising the English translation.

\section{References}

Albuquerque MC, Brasil-Sato MC. First report of Calyptospora sp. (Apicomplexa, Calyptosporidae) in forage characid fish from the Três Marias Reservoir, São Francisco Basin, Brazil. Eur J Protistol 2010; 46(2): 150-152. PMid:20163938.

Azevedo C, Matos P, Matos E. Morphological data of Calyptospora spinosa n. sp. (Apicomplexa, Calyptosporidae) parasite of Crenicichla lepidota Heckel, 1840 (Teleostei) from Amazon River. Eur J Protistol 1993; 29(2): 171-175. http://dx.doi.org/10.1016/ S0932-4739(11)80270-1

Azevedo C, Matos P, Matos E. Ultrastructural data on sporogony of the coccidian parasite Calyptospora spinosa from the liver of the Amazonian fish, Crenicichla lepidota Heckel. J Fish Dis 1995; 18(6): 475-479. http:// dx.doi.org/10.1111/j.1365-2761.1995.tb00351.x

Békési L, Molnár K. Calyptospora tucunarensis n. sp. (Apicomplexa: Sporozoea) from liver of tucunare Cichla ocellaris in Brazil. Syst Parasitol 1991; 18(2):127-132. http://dx.doi.org/10.1007/BF00017665

Bonar C, Poynton SL, Schulma FY, Rietcheck RL, Garner MM. Hepatic Calyptospora sp. (Apicomplexa) infection in a wild-born, aquarium-held clutch of juvenile arapaima Arapaima gigas (Osteoglossidae). Dis Aquat Organ 2006; 70(1-2): 81-92. PMid:16875394. http://dx.doi. org/10.3354/dao070081

Cheung PJ, Nigrelli RF, Ruggieri GD. Calyptospora serrasalmi sp. nov. (Coccidia: Calyptosporidae) from liver of the black piranha, Serrasalmus niger Schomburgk. J Aquaricult Aquat Sci 1986; 4(3): 54-57.

Casal G, Padovan I, Matos E, Padovan P, Matos P, Magalhães A, et al. Morphological and ultrastructural redescription of Calyptospora serrasalmi Cheung, Nigrelli \& Ruggieri, 1986 (Apicomplexa: Calyptosporidae), a parasite found in two new host species of the genus Serrasalmus. BrazJ Morphol Sci 2007; 24(1): 11-16.

Davies PJ, Ball SP. The biology of fish coccidia. Adv Parasitol 1993; 32: 293-366. http://dx.doi.org/10.1016/S0065-308X(08)60210-9

Duszynski DW, Solangi MA, Overstreet RM. A new and unusual eimerian (Protozoa: Eimeriidae) from the kiver of the Gulf killifish, Fundulus grandis. J Wildl Dis 1979; 15: 543-552. PMid:522224.

Fournie JW, Hawkins WE, Overstreet RM. Calyptospora empristica n. sp. (Eimeriorina: Calyptosporidae) from the liver of the starhead topminnow, Fundulus notti.J Eukaryot Microbiol 1985; 32(3): 542-547. http://dx.doi. org/10.1111/j.1550-7408.1985.tb04058.x

Matos E, Casal PM, Corral L, Azevedo C. Microrganismos parasitos de animais aquáticos da Amazônia. In: Ranzani-Paiva MJ, Takemoto RM, Lizana MAP. Sanidade de organismos aquáticos. São Paulo: Varela; 2004. p. 159-178.

Molnár K. Phylum Apicomplexa. In: Woo PTK. Fish Diseases and disorders: protozoan and metazoan infections. Cambridge: Cabi Publishing; 2006. p. 183-204.

Overstreet RM, Hawkins WE, FournieJW. The coccidian genus Calyptospora n. g. and Family Calyptosporidae n. fam. (Apicomplexa), with members infecting primarily fishes. J Eukaryot Microbiol 1984; 31(2): 332-339. http://dx.doi.org/10.1111/j.1550-7408.1984.tb02972.x 